University of Louisville

ThinkIR: The University of Louisville's Institutional Repository

Electronic Theses and Dissertations

$1-1927$

\title{
The Renaissance paradox in Spenser.
}

Juretta V. Bamber 1898-1981

University of Louisville

Follow this and additional works at: https://ir.library.louisville.edu/etd

Part of the English Language and Literature Commons

\section{Recommended Citation}

Bamber, Juretta V. 1898-1981, "The Renaissance paradox in Spenser." (1927). Electronic Theses and Dissertations. Paper 65.

https://doi.org/10.18297/etd/65

This Master's Thesis is brought to you for free and open access by ThinkIR: The University of Louisville's Institutional Repository. It has been accepted for inclusion in Electronic Theses and Dissertations by an authorized administrator of ThinkIR: The University of Louisville's Institutional Repository. This title appears here courtesy of the author, who has retained all other copyrights. For more information, please contact thinkir@louisville.edu. 


\title{
UNIVERSITY OF LOUISVILLE
}

\section{THE RENAISSANCE PARADOX IN SPENSER}

\author{
A Dissertation \\ Submitted to the Faculty \\ or the Graduate School of \\ The College of Arts and Sciences \\ In Partial Fulfillment of the Requirement $s$ \\ For the Degree of \\ MASTER OF ARTS
}

DEPARTM ENT OF ENGLISH

by

JURETTA V. BAMBER 


\section{CONTENTS}

The Renaissance Ideal

The Puritan Ideal

Spenser and the Renaissance paradox

Harmonization of Contrasting Forces

Bibliography
Page 1

Page ?

Page 22

Page 38 
THE RENA I SSANCE I DEAL 


\section{THE RENAISSANCE IDEAL}

The complex phenomenon known as the $R$ enaissance stimulated man with an insatiable curiosity in all things that had to do with human life and activity. The powerful searchlight of curiosity was especially turned on the ancient world - its learning, art, and literature - with a resultant diffusion of light so wi despread that its influ ence is incalculable. In Italy, which in the fourteenth century saw the dawn of the Renaissance, "a glorious sumptuousness"l of life prevailed. Ostentation, manifesting itself in brilliant dress, in beautiful homes, in wealth, and in magnificence of every kind, characterized the now movement. The Renaissance insisted on the liberation of social, intellectual, and aesthetic faculties. 2 In Italy, for the first time after the overthrow of ancient civilization, man, affected by the new intellectual light, acted as a free agent in thought and in dead.3 But for the emphasis on and the development of the individual, the Renaissanc e could not have been; for as Hulme explains, "It is only through the channel of individuality that new thought and new art can come into the world; and thought and art, immaterial though they be, are the matrix that

1. Claviere, R. de $\mathbb{M}_{\text {., The }}$ Women of the Renaissance, p. 225. Trans. by George Herbert Ely.

2. Hulme, Renaissance and Reformation, pp. 64-65.

3. I bid. 
shapes the issues of life."I The search for the individual naturally led to ancient Greece, whose people had recognized the importance of individuality; "it is to this that their supreme achievements in art were largely due."z William H. Woodward, in his Education during the Renaissance, 3 states that enthusiasm for antiquity was born of two motives: first, patriotic sentiment; second, aesthetic attraction. Through a deep reading in ancient history, the thinkers of the Renaissance recover ed the wisdom of the ancients to apply to the problems of actual life. 4

It is not the purpose of this study to consider in detail the many intricate phases of the Renaissance; an attempt will be made merely to present the conceptions of beauty and the appeal of beauty during this period. Spingarn, in his Literary Criticism in the Renaissance, states that three conceptions of beauty were in vogue during the Renaissance, as follow: "First, the purely objective conception that beauty is fixed or formal, that it consists in approximating to a certain mechanical or geometrical form, such as roundness, squar eness, or straightness; secondly, the Platonic conception, ethical rather than aesthetic, connecting the beautiful

1. Hulme, op. cit., p. 59.

2. I bid., p. 60 .

3. P. 4 .

4. Mackail, W.H., The Sorings of Helicon, p. 78. 
with the good, and $r$ egarding both as the manifestations of divine power; and thirdly, a more purely aesthetic conception of beauty, connecting it ei ther with grace or conformity, or in a higher sense with whatever is proper or fitting to an object."

Though the $R$ enaissance delighted in every expression of beauty, it especially revelled in that type which on $\theta$ could hear and smell and touch and see - sensuous beauty. ${ }^{1}$ Delight in beauty of the nude, admired by the ancient Greeks, became a passion in the Renaissance. The belief that the human form, especially that of woman, was the loveli est of or eated things was evidenced in the manifestations of physical beauty everywhere - in salons, at public resorts, along promenades, and even on the walls of churches and cathedrals. ${ }^{2}$ Claviere states: "...... the sight of the human form appear ed absolutely conformable to a esthetics and philosophy, so mich so that a whole generation of well-intentioned tutors, ......... set themselves ingeniously to explain to young psople the religious significance of nudities. It was on the same principle that Frangois de Moulins, the excellent eleric especially entrusted with the moral instruction of young - Francis I., inserted in his manuscripts a picture of the Graces, and taught his young pupil that Charity is rightly

1. Fl etcher, J.B., The Religion of Beauty in Woman, p. 2. 2. Claviere, op. cit., p. 203 . 
represented as a nude figure in order to symbolise her generosity, or rather to bring it more vividly home to one." I Michelangelo proved the possibility of glorifying "the human figure fearlessly and unblushingly without weakening in any way the general concepti on of vigour and chastity."2 Platonist aesthetics is largely responsible for this attitude, for it taught "that the human body is the perfect type of terrestrial beauty, just as the human soul is the queen of the universe." 3 Not all, however, derived such noble effects from the aesthetic idea; many more got from the exhibitions of the academies a wholly different type of entertainment. 4 Moral laxity and undue license naturally followed. The explanation is not hard to find. The moral pendulum merely swung from the restraint of the Middle Ages to the opposite extreme during the Renaissance. As Hulme, referring to the "wide range of expression, from superlative intellectual activity and artistic areation to the depths of pagan sensuality," explains; "The standards of internal moral. control had not yet been developed, and those of external control had been discarded. It is this that produced such violent contrasts of emotion and conduct ...." " 5

There developed in the later fifteenth century a kind of divine worship of beautiful women. ${ }^{6}$ clavi ere makes the

1. Claviere, Op. cit., p. 203.

2. Ibid., p. 202.

3. Ibid., p. 202 .

4. I bid., p. 203.

5. Hulme, Op. cit., p. 7I

6. Fl etcher, Op. cit., p. 1 . 
point that wornan's mission was "to $r$ epresent beauty, and consequently love ........ the inspiration of noble thoughts and great actions." I According to one interpreter of Platonism, Cardinal Bembo, "Love is ........ a ray of divine beauty caught through the medium of a woman's face. Unhappily the senses interpose; a man sees in the body itself the source of beauty and longs to enjoy it. How deceived he is! It is not beauty that is thus enjoyed; an appetite is appeased, and soon comes satiety, weariness and often aversion." 2

Platonism stood for intell ectual beauty, a beauty free and apart from that type which affected the senses and the emotions. How ever, by contemplating beauty in visible form, especially in woman, one could get an appreciation of pure, d etached spiritual beauty. The Italian, with his warm Latin temperament, was perfectly content to gaze on mundane loveliness, void of any spiritual purpose. As the passionate appeal of the senses increased, the gul $f$ between the Platonic ideal and the sensuous ideal became definitely established. So dominant was the sensuous appeal over the Platonic that the Renaissance movernent became characterized by the former and synonymous with it. Thus two widely

1. Op. cit., p. 161.

2. Claviere, op. cit., p.160. 
differing conceptions of that intangible force - beauty were defined. Fach was clearly contradictory to the other.

Elizabethan England, which felt the Renaissance influ ence chiefly in literature rather than in the other arts, ${ }^{1}$ possessed what might be called an inherent love of the beautiful. Miss Phoebe Sheavyn has analyzed this "instinctive" characteristic: "Some indulged it to the utmost; others fearful of its temptations, sternly endeavored to repress it. Not that they understood how to distinguish the purer, chaster forms of loveliness from the merely gaudy and pretentious; they were easily misled, but in literature, in architecture, in dress, in pageants, they sought eagerly for beauty, trusting only too often to find it in elaborate decorativeness." 2

I propose to show further on how an exquisite sense of beauty in an outstanding Elizabethan - Edmund Spenser - manifested itself, in his poetry, along Renaissance lines.

The Renaissance, quickening continental Europe, brought with it a joy of life such as, most likely, had not been previously felt in the world. "Sadness conceal ed itself, joy kept the whole world dancing to its merry pipe." 3

1. Boas, Hahn, Social Backgrounds of English Literature,p.77.

2. Sheavyn, Literary Patronage in the Elizab ethan Age, p.193.

3. Claviere, op. cit., p. 226 . 
THE PURITAN IDEAL 


\section{THE PURITAN I DEAL}

The Renaissance enabled man to discover himself to develop his individuality. Man gave up his reliance upon authority and began to think for himself. Freedom of thought, consequentiy, became manifest ed in religious as well as in secular matters.1 A large and increasing number of people earnestly advocated religi ous reform, and the dissenters became known as Puritans. Since Puritanism had a definite and a far-reaching influence on the literary, as well as the political, history of England, it is appropriate at this point to set forth some idea of the meaning of the word. Many definitions of the inclusive term Puritanism have been attempted. Most of them are partially satisfactory, but in order to get a comprehensive idea of the word it is necessary to bring together parts of several definitions. Puritanism, as manifested in the sixteenth century, was "the effort to secure reform, either partial or complete, in spiritual or political matters, or in both"; 2 the "reverence for Scripture and for the sovereign majesty of God, a severe morality, popular sympathies"; 3 "the effort to rid life, or some phases of it, of the evils that have enwrapped it"; 4 and lastly, "Puritanism indicated a revolt of the

1. Hulme, Op. cit., p. 67.

2. Padelford, F.M.," "Spenser and the Spirit of Puritanism," Modern Philology, XIV, 1916, pp. 31-44.

3. Brown, J., The English puritans, as quoted by Padelford in his article in Molern Philology, cited above.

4. Thompson, E.N.S., The Gont roversy between the Puritans and the Stage, as quoted by padel ford, cited above. 
religious conscience of the nation against the arts and manners of the Renaissance ......." 1

During Elizabeth's reigh the Puritans, with a Calvinistic program, were chi efly concerned with "(1) change in organization and procedure of the church in conformity with the Presbyterian system; and (3) reform of the whole attitude of society toward life."2 Puritanism came into existence for the purpose of enforcing its cardinal doctrines of election and justification, insisting that all else which the Church of England had to offer be discarded. ${ }^{3}$ The main doctrines of Calvinistic Puritanism are here briefly extracted from Matthew Arnold' g summary:

God, through his grace and love, predestined to everlasting life, a certain number of angels and $m e n$, without any foresight of faith or good works in them; others $\mathrm{He}$ for eordained to everlasting death. Adam and Eve, by eating the forbidden fruit, broke the covenant which God had made with them, assuring them of everlasting life in return for perfect obedience, and ther eby made themselves and their posterity liable to everlasting death. They became by this act enemi es to God and to all spiritual good. This, according to Caivinism, is the original sin.

However, since man has no power to rise out of his falien state, the covenant of redemption, made between God the Father and God the Son before the world began, greatly affects his condition. The covenant of the redemption is this: God gave his chosen to the Son provided that He would humble himself to take on human

1. Bncyclopedia Britannica, p. 92 .

2. Padelford, op. cit.

3. Arnold, Matthew, St. Paul and Protestantism, pp. 2-3. 
nature, give obedience in their name and suffer the death of the cross and by so doing $\mathrm{He}$ should ransom and $r e d e m$ them and purchase for them righteousress and eternal life. The Son accepted the condition and in due time came into the world.

God through the $\mathrm{Bibl}$ e has $\mathrm{revealed}$ to man His covenant of grace and redemption. The elect are called by the Holy Spirit, the third person in the Trinity, who applies the redemption purchased by the son by working faith in them. As soon as the elect give their consent heartily and repentantly to the covenant of grace, God justifi ed them by imputing them that perfect obedience which Christ gave to the law. They are also sanctified by God; carnal lust are destroy ed in them, and the practice of holiness is put in their power. Good works done by the chosen are accepted and rewarded; but works done by the rejected ones cannot please God, for such works are considered sinful. The elect, after justification and sanctification, cannot fall from grace, but shall persevere to the end and be eternally saved. After death they remain in glory forever with $\mathrm{Christ;}$ but the wicked are sent to hell with Satan. 1

The puritans, setting forth and insisting on their points of doctrine as the pure, simple religion followed by the Apostolic church, were bent on ridding the Church of all ceremonies or matters of discipline which in any way $r$ eminded them of Rome or popishness. There was always the fear that the High church party might be led back in to the fold of the catholics. The controversy between the puritans and the Anglicans began over the vestments which the ol agy were required to wear, ${ }^{2}$ a matter significant in that it indicat ed the beginning of self-consciousness of puritanism. ${ }^{3}$

1. Arnold, Matthew, St. Paul and Protestantism, pp. 10-12. 3. Taylor, H.O., Thought and Exoression in the Sixteenth Century, Vol. II, p. 155 .

3. Taylor, op. cit., p. 136. 
In attempting to present the Puritan side, I shall quote Dr. J. J. Higginson, who very concisely states in his Spenser's Sheoherd's Calender non-con formist objections to the Church of England. "The chi ef matters in the Church which Cartwright and the Puritans disliked were as follows: the whole order of ecclesiastical precedence, archbishops, bishops, archdeacons, deans, chapters, chancellors, commissaries, and other officials; the authority of the Church to ordain matters not expressly commanded by scripture; the appointment of ministers by bishops, lay patrons, and the Crown; the appointment of ministers without a special pastoral charge; the non$r$ esidence of ministers and their holding of a plurality of benefices; the appointment of ministers who could read only and not preach; the use of the clerical vestments; the use of the Communion Book; the observation of holy-days and rembrance of saints; the cathedral mode of wor ship accompanied with chanting of prayers and music of organs; certain rites and ceremonies relating to communion, marriage, burial, baptism, purification of women, confirmation, and many others, which were inveighed against with a bitterness which now seems entirely disproportionate to their importance. $n^{1}$

The University of Cambridge became the seche of

1. Higginson, J.J., Spenser's Shepherd's Calender, pp. 24-25. 
sharp religious contention. During the seven years which Spenser spent there from May 20, 1569, to June $26,1576,1$ the University was persistentiy agitated by controversy between the Puritans and the Anglicans. Thomas Cartwright, the Puritan protagonist opposed by Whitgift, vice-chancellor of the University and Master of Trinity, was expelled from the University in 1572. He was extremely popular, and it is not at all unlikely that Spenser sympathized with him. During the period refer red to, "many cross-currents were at work, and it is not always possible to draw a hard and fast line between Puritan and Anglican. Many $m$ en who were at first violent opponents of the Anglican Church later conformed and gained high preferment, "బ evidently with the purpose of reforming the church from within. Thus the Puritan-Anglican controversy raged, increasing in force with the passage of time. The Puritans first objected to discipline; later they became involved over doctrine; and finally they were distinguished as a definite social factor $r$ evolving about a strict and severe code of morality, which developed into bigotry. "Puritanism was a rebirth of morality, similar to the rebirth of learning." 3 Definite

1. Higginson, J.J., op. cit., p. 30 .

2. Higginson, J.J., op. cit., p. 36.

3. Boas, Hahn, op. cit., p. 123. 
features characterized the rebirth of both morality and 1 earning. The $R$ enaissance was "essentially pagan in its interests"; ${ }^{1}$ but in England there developed, while the Renaissance was in full progress, a spiritual consciousness - a strict morality to counterbalance the laxness of the Renaissance. The ideals of the two movements were directly opposite. The literature of the time reflects the ideals of both, and it is difficult to determine which has the more far-reaching influence. The Puritans, unduly impressed with the seriousness of life, found no time for the enjoyment of it. Art they could not understand nor harmonize with their ideas of morality. The Puritans "asserted that the poetry of the period ministered only to sensual pleasures"; 3 they protested that current poetry and plays failed to afford moral instruction (which should be, according to their views, the sole aim of poetry) and that they should ther efore be condemned. "The growth of Puritanism encouraged nov elists to attack the 'Gircean charms' of Italy and point out their pitfalls and perils." 4 Roger Ascham, the learned tutor of Queen Elizabeth,

1. Boas, Hahn, Social Backgrounds of Engli sh Literature, p.123. 2. Boas, Hahn, Op. cit., p. 103.

3. Clark, D.L., Rhetoric and Poetry in the Renaissance, p.144. 4. Einst ein, L., The Italian Renaissance in England, p.i56. 
attacked the Italianate Englishman and deplor ed more than the corrupt life in Italy, which young Englishmen took as an example, the books and immoral romances translat ed from Italian into English.

In the light of the for egoing, Spenser's religious position must be examined. He has been called an outand-out Puritan, and he has likewise been called a Low Churchman. A High Church party and a Low Church party existed within the Church of England itself. Not all who were interested in religious reform were willing to leave the Established Church. I The Low Church party was composed of those who, recognizing church abuses, wished to accomplish reforms from within. The difference arose over church discipline. On e must remember that Anglican, as well as Puritan, acobet ed Calvinistic doctrine, at least a portion of it. In attempting to analyze Spenser's religious position, I shall confine my discussion to the theological views which he expressed in The Shepheardes Galender and in the first book of The Faerie Queene.

The February eclogue was directed against the governmental policy of Lord Burghley, Prime Minister, who in Mary's reign, had established himself with the

1. Boas, Hahn, op. cit., p. 123.

2. Higginson, J.J., op. cit. 
Catholics. All those who were not in accord with the government were classed as Puritans, but this distinction rested on a political basis only. It would therefore seem that Spenser's views in this eclogue would align him with the Puritans.

The May, July, and Septamber eclogues are concerned almost wholly with ecclesiastical matters.l Dr. Higginson, in his study of The Shepheardes calender, has analyz ed by car eful research the events allud ed to in the different eologues. His findings in the May eclogue bring him to the conclusion that Spenser was dissatisfied with "the Anglican Church, its constitution, and at tendant corruptions, and with the policy of those who ruled it, and that the feeling a rose from his residence in Cambridge and his association with men of Puritan opinions during a tumultuous period of revolt against academic and State authority. $n^{2}$

The July eclogue censures the princely living of the prelates, their corrupt methods in buying their bishoprics, ${ }^{3}$ their use of pompous titles, the heaping up of money at the expense of their flocks, ${ }^{4}$ and the idleness and lordly living of the bi shops who maintain a an unl earned ministry. ${ }^{5}$ spenser, in this eclogue, pays a

1. Higginson, J.J., op.cit., p. 39.

2. Ibid., p. 98 .

3. Ibid., p. 105.

4. Ibid., p. $10 \%$.

5. Ibid., p. 109. 
tribute to Archbishop Grindal, under the name of Algrind, who had Puritan sympathies.

Spenser's fiercest satire comes out in the September eclogue in which he attacks: "(1) the traffic in Church livings and licenses (11.36-7), (3) the system of fines (11.38-40), (3) the unfair oppression of the lower clergy by the higher, viz. the Puritans by the Anglicans (11.40-1), and (4) the pride of the ecclesiasts $(11.42-46)$."1 Spenser also praises a godly bishop, identified in most cases as Bishop Young, whom he later served, although Dr. Higginson takes him to be Dr. Richard Cox, a father of the English Church. In either case, however, Spenser was praising an Anglican church official.

The above mention ed eclogues, voicing, as they do, the Puritan attack, might lead one to believe that Spenser was definitely allied with the Puritans; yet at the same time that Spenser was attacking abuses within the Church, he was praising godly members of the clergy. This fact alone is sufficient to show that Spenser was not an extremist.

Calvinistic doctrines are especially depicted

1. Higginson, J.J., op. cit., pp. 113-4. 
in The Faerie Queene, Book I, Canto $x .^{1}$ The Redcross Knight, released from imprisonment in the House of pryde, shuns the broad highway of pleasure in the world and, and conducted by Una, goes to the House of Holiness. There Fidelia - Faith - instructs him, at Una's request, about God, grace, justice, and free will. The knight, contemplating the perfection of heavenly grace, soon grew to abhor his wretched condition and wi shed to end his life. Speranza Hope - comforts him; Patience comes to his aid, and $R$ epentance restores him to health. Charissa - Charityinstmicts the knight in love and righteousness, and shows him the path to heaven. Mercy shows him the seven duties of mankind - to lodge the homeless; to feed the hungry and give drink to the thirsty; to clothe the naked; to succor the prisoner; to care for the sick; to bury the dead; and to care for the orphan. The knight is escorted to Heavenly Contemplation, who shows him the way to the New Jerusalem. All this is thorough-going Puritan Caivinism. Man is moval by faith to $r$ epentance, and through faith he is justified and sanctified as one of the elect. The Redoross Knight or Holiness knows by means of Calvin," Modern Philology, XII, 1914, pp.1-18. 
Heavenly Contemplation that he is one of the elect. He is permitted to behold the $\mathbb{N}$ ew Jemsal em built for God's chosen, who are bought by the redemption of christ. The purpose of Book I is to set forth the attainment of Holiness, which is comparable to Calvinistic Righteousness; and Canto $x$, as shown above, is definitely Puritan.

Politically and apparently theologically Spenser agreed with the puritans; yet he accepted employment under the Anglican hi erarchy. The fact that Spenser was secretary to John Young, Bishop of Rochester, 1 seems to argue that he was not definitely allied with the Puritans in their religious controversy. Notwithstanding any personal scruples he might have had in the matter, it is out of the question to suppose that an Anglican bi shop would have employed a puritan secretary. Spenser's employment under Leicester in the following year $(1579)^{2}$ allies him with the Puritans from a political standpoint, since all those who opposed the government were class as Puritans. In the same year, 1579,3 The shepheard es calender was published, containing both political and religious satire against the Anglicans. Spenser, however, does

1. Carpenter, F.I., A Reference Guide to 터mund Soenser, p.14. 2. Ibid., p. 15. 3. Ibid., p. 15. 
not restrict his satire to one side but alludes to the Puritans, Dean Church believes, when he speaks of "our lat too nice fools" and of "that ungracious orew which faines demurest grace." 1 Professor A. H. Tolman ${ }^{2}$ argues that Spenser is a Low Churchman because of his friendship with Harvey, whose religious views are well known. The reasons for such a conclusion are appar ently sound. Harvey, he states with apparent certainty, "was a broad-minded Low Churchman, accepting and defending the episcopal system but with no illusions about it and no extreme views. $m^{3}$ The close friendship between Spenser and Harvey could not have existed, Professor Tolman believes, "without substantial agreement on religious questions, " especially since agitation over religious matters during the residence of the two men at the University of Cambridge was at all times very keen. Bishop Young was a good friend of Harvey's; and Professor Tolman thinks that the friendship of Bishop Young for both Spenser and Harvey furnishes distinct corroboration of the presumption that the two men were agreed in their religious views. ${ }^{5}$ Hatred of Rome, which Spenser shared with others, was characteristi of the Iow Church party as well as of the Puritans.

What conclusion do these ind efinite, incomplete bits

1. Church, Spenser, p. 115, quot od by Higginson in Spenser's Sheoheardes Calend er, p. 155. (F.2., VII, vii, 35).

2. Tolman, A. H., "The Relation of spenser and Harvey to Puritanism, " Modern Philology, XV, 1918, p. 554.

3. Ibid., p. 564 .

4. Ibid., p. 555.

5. I bid., p. 557 . 
of information and infer ences lead to? Granting that Spens er was a Low churchman, he yet manifested many Puritan characteristics. The "sage and serious Spenser" was considered an excellent teacher by the great Puritan who followed him and absor bed his philosophy - Milton. Life oppressed "the poet's poet" at times with its seriousness. He railed at the luxury and looseness of the court. A didactic aim motivated his art. He never entirely lost sight of his moral purpose to teach righteousness by example. Spenser considered his Faerie Queene no less than a work in ethics, as evidenced by the following incident related by Dowden. "One day Spenser's friend Bryskett, in his cottage near Dublin, gathered about him a circle of distinguished acquaintances; and conversing on the subject of eithics, which he wished were worthily handled in English, 'wher eby our youth might speedily enter into the right course of vertuous life,' he turned to Spenser with an embarrassing request - that Spenser should forthwith proce to deliver a discourse on the virtues and vices, and give the company a taste of true moral philosophy. Spenser naturally excused himself, and pleaded on his own behalf that, though he could not improvise a lecture on ethics, he had actually in hand a work which might in some sort satisfy his friend's desire: 'For sure I am, that it is not unknowne unto 
you, that I have already undertaken a work tending to the same effect, which is in heroical verse under the title of a "Faerie Queene" to represent all the moral vertues, assigning to every vertue a Knight to be the patron and defender of the same, in whose actions and feats of arms and chivalry the operations of that vertue, wher eof he is the protector, are to be expressed, and the vices and unruly appetites that oppose themselves against the same, to be beaten down and overcome. 1

Spenser att mpted, and achieved to a certain extent, the personification of all the moral virtues, which were to be militant and triumphant over vices and unruly appetites. Yet Spenser undoubtedly did not belong to the group of Puritans who condemned poetry and plays for their immorality and sensuousness. He did not find Italy to be a den of corruption as did the Puritans, but he found there a storehouse of inspiration for his exquisite sense of beauty. It is quite logical to believe that a man of Spenser's disposition, holding the doctrine of the golden mean, would take a middle course and show temperance in religion as well as in other matters. I accordingly believe that Spenser was a Low Churchman, willing to attack the

Dowden, Edward, Transcripts and Studies, "Spenser the Poet and $\mathrm{I}$ eacher, "pp. $2 \overline{84-85}$. 
abuses in the Church from within, Puritan in his political attitude.

The good was the beautiful to Spenser -

"Whatever fair is, is by nature good." 1

and herein his puritan morality joins hands with Renaissance Platonism. Spenser, then, in my opinion, is what Dean Church calls a "Puritan Platonist." One can better feel the significance of such a term than define it. By using this designation, I mean to convey that Spenser was an exponent of the strict moral purity of the puritans and of the undefiled, intell ectual ideal of Platonism, both ideals standing for the exaltation of the spirit.

1. "An Hymne in Honour of Beautie," 1. 139. 
SPENSER AND THE RENAISSANCE PARADOX 
SPENSER AND THE RENAISSANCE PARADOX

There were during the $R$ enaissance $t$ wo conceptions of beauty - that of the mind and that of the body. According to Plato, true beauty was only of the mind. The Renaissance interpretation of this Greek philosophy, known as Neo-Platonism, held that contemplation of earthly beauty enabled one to apprehend and appreciate abstract beauty. Objective beauty became idealized in woman. The Renaissance follow ed the Greek example and glorified the human body in the nude. Some, like Michelangelo, derived from the unclad human figure a lofty morality; others got from it only delight for the senses. I Naturally, such idealism could not inspire the majority of frail human beings. Laxity and license $r$ eigned, only to be checked by the severe restraint of the Reformation.

The Renaissance saw in the human body the perfection of grace and loveliness. The Puritan believed that the body should be "sacrificed willingly to the needs of the soul, and that this might the more readily be accomplished men were bidden to loathe and revile it. They were to meditate in their chambers on this wise: ' 0 what a filthy, unclean, and ugglesome carcase do I bear about with me, that for very shame had need to be covered with garments. " ${ }^{2}$

1. Claviare, Op. cit., pp. 202, 203.

2. Sheavyn, Phoebe, The Literary Proression in the miza

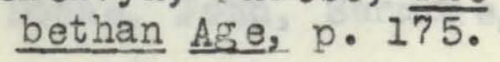


The typical puritan attitude toward the body is voiced a little later by Dr. Donne, who, like Spenser, felt the struggle between soul and sense - though to a greater degree - in such passages as the following:

"This ourded milke, this poor unlettered whelpe My body, could beyond escape or helpe, Infect thee (soul) with original sinne, and thou Could st neither then refuse, nor leave it now."I

Corruption of the flesh is also the theme of the passage -

"All flesh is sinful flesh; sinful so, as that it is the mother of sin, it occasions sin."2

Spenser at times loathed the human body and pictured it as the most repulsive object conceivable to one's imagination. Lust, that Grendel-like figure, covered with hair, with ears larger than an elephant's, with huge teeth, with his nether lip hanging down and his great nose empurpled with blood, is an outward manifestation of inward foulness. Occasion, Envie, and Detraction are likewise unnatural oreatures, -grisly, loathsome monsters; and in each case the body is the manifestation of a corrupt soul. Spenser thought of the body as an object of loathing as well as an object of delight.

"Of all Gods workes, which doe this world adorne, There is no one more faire and excellent, Then is mans body both for powre and forme, Whiles it is kept in sober government;

1. Donne, John, Poetical Works, "Of the Progress of the Soul, " - On the Second Anniversary of the death of Elizabeth Drury.

2. Donne, John, Sermons, Alford I; 374. 
But none then it more fowle and indecent, Dist empred through misrule and passions bace: It growes a monster, and incontinent

Doth loose his dignity and native grace." I

Spenser lavished his descriptive pow er equally on his detestable and his lovely oreatures. His repulsive characters are as repulsive as his delight ful characters are delightful. The human body represented to him that which was evil and that which was good. There was the foulness of cormution, which was to be loathed and despised. On the othar hand, there was the beauty of holiness, of truth, of chastity. The personifications of these virtues were to be worshipped and deified.

Spenser's Platonic philosophy was responsible for his belief that beauty of soul oreates beauty of body, the body being but the reflection of soul goodness and beauty. Carrying out this belief, Spenser made his good characters beautiful and his evil characters, with few exceptions, repulsive. Such exceptions as Duessa and the faise Florimell do have a beauty after a fashion not real beauty - which is able to deceive the unwary. Even Acrasia, as one critic points out, is not originally bad but a virtue carried to the extreme, which becomes a vice, ${ }^{2}$ a doctrine in keeping with Spenser's philosophy of the golden mean.

1. The Faerie Queene, II, ix, 1 .

2. Cory, H. E., Edmund Spenser: A Critical Study, p. 465. 
Fdmund Spenser had a comprehensive sense of beauty. A beautiful scene, the song of a bird, and especially the human form never failed to thrill him. He inherited the typical Renaissance appetite for sensuous beauty. But woman most appealed to him. B eauty to Spenser was a religion, of which Woman was the high priestess. The true beauty, he believed with Plato, is that of the mind and "is much more praysd of me." In spite of this statement, Spenser, as a matter of fact, threm his full force and put his utmost enthusiasms into his descriptions of sensuous charms. So engrossed did he become in his own lovely creations that he found it necessary - his conscience evidently annoyed him - to remind himself continually of his high moral purpose.

"The waies, through which my weary steps I guyde, In this delightfull land of Faery, Are so exceeding spacious and wyde, And sprinckled with such swe et variety of all that pleasant is to eare or ey e, That I, nigh ravisht with rare thoughts delight, My tedious travell doe forget ther ely; And when I gin to feele decay of might, It strength to me supplies, and chears my dulled spright. Spirit and body, soul and sense, continually strive for ascendancy. Spenser is consciously a puritan, subconsciously a Renaissance hedonist.

In the light of Platonic philosophy, Spenser states in his "An Hymne in Honour of Beautie" and "An Hymne of

1. Church, R.M., Spenser (E.M.L.), p. 144.

3. The Faerie Queene, VI, Preface 1 . 
Heavenly Beautie" that beauty is heaven-born and fashioned after a pattern of perfect Beautie, which no mortal ey e can see. Beauty is not merely, as one often mistakes,

"An outward shew of things that only seeme." I Real beauty cannot pass away; it is permanent. The fairer the body is, the more heavenly light it possesses,

"For of the soule the bodie forme doth take, "2 (with certain exceptions ${ }^{3}$ ).

An examination of the "Anoretti" and the "Epithalamion" reveals exquisite descriptions of sensuous beauty alternating with lofty delineations of spiritual excellence. Though Spenser portrays ideal beauty in an exalted mood, he does not enter into such passages with the whole-hearted abandon and enthusiastic delight characteristic of the fleshly passages. Throughout the love sonnets the beauty of the beloved's body inspires the lover "Burning in Mames of pure and chast desyre, " 4 to the contemplation of spiritual beauty. The loved one

" ................ doth in her self containe All this worlds riches that may farre be found: If saphyres, loe! her eies be saphyres plaine; If mbies, loe! her lips be rubies sound; If pearles, hir teeth be pearles both pure and round; If yvorie, her forhead yvory weene; If gold, her locks are finest gold on ground; If silver, her faire hands are silver she ene:" 5

1. "An Hymne in Honour of Beautie," 1. 91.

2. Ibid., 1. 132.

3. Ibid., 11.141-147.

4. "Amoret ti," XXII.

5. Ibid,, XV. 
Here Spenser rouses himself from his body worship to ponder that

" .... that which fairest is but few behold, Her mind, adornd with vertues mamifold." I

One feature alone is sufficient to enrapture the ever-susceptible one:

"What guyle is this, that those her golden tresses She doth attyre under a net of gold, And with sly skill so cunningly them dresses, That which is gold or heare may scarce be told? Is it that mens frayle eyes, which gaze too bold, She may entangle in that golden snare, And being caught, may craftily en fold Theyr weaker harts, which are not wel aware?"2

The sense of smell is also gratified:

"Coming to kisse her lyps, (such grace I found) Me se emd I smelt a gardin of swe et flowres, That dainty odours from them threw around, For damzels fit to decke their lovers bowres. Her lips did smell lyke unto gilly flowers;

Her ruddy che ekes lyke un to roses red; Her snowy browes lyke budded bellamoures; Her lovely eyes lyke pincks but newly spred; Her goodiy bosome lyke a strawberry bed; Her neck lyke to a bounch of cullambynes; Her brest lyke lillyes, ere theyr leaves be shed; Her nipples lyke yong blossomd jessemynes. Such fragrant flowres doe give most odorous smell, But her sweet odour did them all excell." 3

Then the beauty of mind, the platonic ideal is emphasized:

"Men call you fayre, and you doe credit it, For that your selfe ye dayly such doe see: But the trew fayre, that is the gentle wit And vertuous mind, is much more praysd of me. For all the rest, how ever fayre it be, Shall turne to nought and 100 se that glorious hew: But onely that is permanent, and free From frayle corruption, that doth flesh ensew.

1. "Amoretti," XV.

2. Ibid., XXXVII.

3. I bid., IXIV. 
That is true beautie: that doth argue you To be divine, and borne of heavenly seed, Deriv'd from that fayre Spirit from whom al true And perfect beauty did at first proceed. He onely fayre, and what he fayre hath made; All other fayre, lyke flowres, untymely fade." I

Again the poet sees only the body of the loved one:

"Fayre bosome, fraught with vertues richest tresure, The neast of love, the lodging of delight, The bowre of blisse, the paradice of pleasure, The sacred harbour of that hevenly spright; How was I ravisht with your lovely sight, And my frayle thoughts too rashly led astray! Whiles diving deepe through amorous insight, On the sweet spoyle of beautie they did pray, And twixt her paps, like early fruit in May, Whose harvest seemd to hasten now apace, They loosely did theyr wanton winges display, And there to rest themselves did boldly place. Sweet thoughts, I envy your so happy rest, Which oft I wisht, yet never was so blest." "z

The following sonnet continues the same type of worship:

"Was it a dreame, or did I see it playne? A goodly table of pure yvory,

All spred with juncats fit to entertayne

The greatest prince with pompous roialty:

Mongst which, there in a silver dish did ly

Twoo golden apples of unvalewd price,

Far passing those which Hercules came by, Or those which Atalanta did entice;

Exceeding sweet, yet voyd of sinfuil vice;

That many sought, yet none could ever taste;

Sweet fruit of pleasure, brought from Paradice By Love himselfe, and in his garden plaste.

$\mathrm{H}$ er brest that table was, so richly spredd;

My thoughts the guests, which would thereon have fedd."

Spenser's purity is ever burning

"In chast desires, on heavenly beauty bound." 4

1. "Amoretti," LXXIX.

2. Ibid., LXXVI.

3. I bid., LXXVII.

4. Ibid., VIII. 
The struggle is pronounced at this point:

"Let not one sparke of filthy lustfull fyre Breake out, that may her sacred peace molest; Ne one light glance of sensually desyre At tempt to work $h \ni r$ gentle mindes unrest: But pure affections bred in spotlesse brest, And modest thoughts breathd from wel tempred sprites, Goe visit her in her chast bowre of rest, Accompanyde with angelick delightes. There fill your selfe with those most joyous sights, The which my selfe could never yet attayne: But speake no word to her of these sad plights, Which her too constant stiffenesse doth constrayn. On ely behold her rare perfection, And bless your fortunes fayre election. "I

Spenser, with his two-fold idea of beauty, evidencing at times the most ardent desire, was also capable of expressing himself in an altogether lofty mood:

"The soverayne beauty which I doo admyre, Witnesse the world how worthy to be prayzed; The light whereof hath kindled heavenly fyre In my fraile spirit, by her from basenesse raysed: That being now with her huge brightnesse dazed, Base thing I can no more endure to view; But looking still on her, I stand amazed At wondrous sight of so celestiall hew." 2

Exuberant on his bridal day, the poet puts his whole soul into the description of his bride:

"Tell me, ye merchants daughters, did ye see So fayre a creature in your towne before, So swe et, so lovely, and so mild as she, Adornd with beautyes grace and vertues store? Her goodly eyes lyke saphyres shining bright, Her for ehead yvory white, Her cheekes lyke apples which the sun hath rudded, Her lips lyke cherryes charming men to byte, Her brest like to a bowle of creame uncmudded, Her paps lyke lyllies budded, Her snowie necke lyke to a marble towre, And all her body like a pallace fayre, Ascending uppe, with many a stately stayre, To honors seat and chastities sweet bowre. Why stand ye still, ye virgins, in amaze, Upon her so to gaze, n3

1. "Amoretti," LXXXIII.

3: "TbidthaIamion," 11. 167-182. 
But the bride possesses a beauty which he delights

in even more than in that of her lovely flesh:

"But if ye saw that which no ey es can see, The inward beauty of her lively spright, Garnisht with heavenly guifts of high degree, Much more then would ye wonder at that sight, And stand astonisht lyke to those which $\mathrm{red}$ Medusaes mazeful hed.

There dwels sweet Love, and constant Chastity, Unspotted Fayth, and comely Womanhood, Regard of Honour, and mild Modesty;

There vertue raynes as que ene in royal throne, And giveth lawes alone, The which the base affections doe obay, And yeeld theyr services unto her will; Ne thought of thing uncomely ever may Thereto approch to tempt her mind to ill. Had ye once se ene these her celestial threasures, And unrevealed pleasures, Then would ye wonder, and her prayses sing, That al the woods should an swer, and your echo ring." I

Convineed of the Plat onic doctrine that beauty and truth are identical, Spenser united the two qualities in his Una (Truth) ${ }^{3}$ whose

" ........................... angels face As the great eye of heaven shyned bright, And made a sunshine in the shady place; Did never mortall eye behold such heavenly grace." 3

The beauty of truth is powerful enough to subdue the "ramping lyon", and the wild woodgods "stand astonied at her beautie bright." Una is heavenly beauty objectified in woman. Her heavenly, not her physical lineaments,

1. "Epithalamion," 11. 185-203.

2. Harrison, J.S., Platonism in English Poetry, p. 3.

3. The Faerie Queene, I, iii, 4 . 
are referred to:

"The blazing bightnesse of her beauties beame, And glorious light of her sunshyny face, To tell, were as to strive against the streame: My ragged rimes are all too mule and bace,

Chaste beauty, like truth-beauty, is heaven born and has the power to fill the beholder with awe and worship. When Artegall saw the wonder of Britomart's beauty, disclosed when he shattered her ventail, his arm was powerless to strike "so divine a beauties excell ence." 2

"And he himselfe long gazing thereupon, At last fell humbly downe upon his knee, And of his wonder made religion, Weening some heaven ly goddesse he did see, n3

Amoret (Love) also bears the heavenly mark:

"............... all in lilly white arayd, With silver streames amongst the linnen stray'd; Like to the Morne, when first her shyning face Hath to the gloomy world it selfe bewray'd: That same was fayrest Amoret in place, Shyning with beauties light and heavenly vertues

Men that can neither see nor divine sapi ence - perfect beauty - may, by beholding God's creations "which he hath made in beauty excellent"

"............ lift themselves up hyer, And learne to love with zealou humble dewty
Th' Etemall Fountaine of that heavenly Beauty. " 5

1. F.Q., I, xii, 23 .

2. $\overline{F \cdot 2}, I V$, vi, $2 I$.

3. F.Q., IV, vi, 22 .

4. F.2., IV, $\mathrm{x}, 52$.

5. "An Hymne of Heavenly Beautie, "11.19-21. 
Una, Amoret, Britomart, and Belphoebe, Spenser's most attractive heroines, illustrate the platonic doctrine that that which is beautiful is good. Their patience, courage, faithfulness, saintliness, and chastity cannot fail to satisfy the most severe Puritan. But Spenser could not dwell on a high plane continually. He constantly alternated between his delight in contemplation of the spirit and of the body. The struggle was an exacting one:

"O harder lesson to learn continence In joyous pleasure then in grievous paine For swe etnesse doth allure the weaker sence So strongly, that unneathes it can refraine From that which feeble nature covets faine."I

Spenser could not have painted enticing pictures of sensuous beauty had he not had, as Dean Church points out $\frac{1}{2}$ a keen sympathy with what he portrayed in minutest detail. He took advantage of ev ery opportunity to satiate his desire. In one incident Atin finds Cymochles (Fierce and Fickle Passion) sojourning

"Amidst a flock of damzelles fresh and gay, That rownd about him dissolute did play Their wanton follies and light meriment; Every of which did loosely disaray Her upper partes of meet habiliments, And shewd them naked, deckt with many ornaments.

"And every of them strove with most delights Him to aggrate, and great est pleasures shew

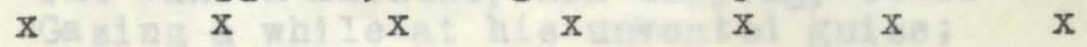

1. Church, R.W., op. cit., p. 155. 
One boastes her beautie, and does yield to vell Her dainty limbes above her tender hips;

Another her out boastes, and all for tryall strips.

"He, like an adder lurking in the weedes,

His wandring thought in deepe desire does steepe

And his frayle eye with spoyle of beauty feedes:

$x \quad x \quad x \quad x \quad x$

Made dronke with drugs of deare voluptuous receipt." I

Spenser lavished the fullness of his genius on

Acrasia and her maidens. He gazed at them longingly

and almost forgot that he had come to capture rather

than to enjoy them. The Bower of Bliss so captivated

him as to make him express his enthusiasm in typical

Renaissance fashion. Guyon walking along,

"Two naked damzelles he therein espyde,

Which, therein bathing, seem ed to contend

And wrestle wantonly, ne car'd to hyde

Their dainty partes from $v e w$ of any which them eyd.

"Sometimes the one would lift the other quight

Above the waters, and then downe again

Her plong, as over mayster ed by might,

Where both awhile would covered remaine,

And each the other from to rise restraine;

The whiles their snowy limbes, as through a vele,

So through the christall waves appeared plaine:

Then suddenly both would themselves unhele, And th' amarous sweet spoiles to gre edy ey es revele.

$\begin{array}{lllll}\mathrm{x} & \mathrm{x} & \mathrm{x} & \mathrm{x}\end{array}$

"Whom such when Guyon saw, he drew him neare, And somewhat gan rel ent his earnest pace;

His stubborne brest gan secret pleasaunce to embrace.

"The wanton maidens, him espying, stood

Gazing a while at his unwonted guise;

Then th' one her selfe low ducked in the flood,

Abasht that her a straunger did avise:

But thother rather higher did arise,

And her two lilly paps aloft displayd,

And all, that might his melting hart entyse

To her delights, she unto him bewrayd:

The rest, hidd underneath, him more desirous made.

1. F.2., II, vi, 32, 33, 34 . 
"With that the other likewise up arose, And her faire lockes, which formerly were bownd Up in one knott, she low adowne did lose:

Which, flowing long and thick, her cloth'd arownd, And th yvorie in golden mantle gownd:

So that faire spectacle from him was reft, Yet that which reft it no lesse faire was fownd: So hidd in lockes and waves from lookers theft, Nought but her lovely face she for his looking left.

"Withall she laughed, and she blusht withall, That blushing to her laughter gave more grace, And laughter to her blushing, as did fall. Now when they spyde the knight to slacke his pace, Them to behold, and in his sparkling face The secrete signes of kindled lust appeare, Their wanton meriments they did encreace, And to him beckned to approch more neare, And shewd him many sights, that corage cold could reare."I

Acrasia herself

"Upon a bed of roses she was layd,

As faint through heat, or dight to pleasant sin, And was arayd, or rather disarayd,

All in a vale of silke and silver thin,

But rather showd more white, if more might bee:

Her subtile web Arachne cannot spin,

Nor the fine nets, which oft we woven see

of scorched deaw, do not in th' ayre more lightly flee.

"Her snowy brest was bare to ready spoyle

Of hungry ei es, which n'ote therewith be fild; And yet through languour of her late swe et toyle, Few drops, more cleare then nectar, forth distild, That like pure orient perles adowne it trild; And her faire eyes, sweet smyling in delight, Moysten ed their faerie beames, with which she thrild Fraile harts, yet quenched not, like starry light, Which, sparckling on the silent waves, does not seeme more bright." 2

1. F.2., II, xi i, 63-68.

2. 
In the very act of pointing out the destructive wiles of the Bower of Bliss, Spenser cannot refrain from revelling in the deliciousness of it all. The poet lauds his virgins to the empyrean, but he lingers longingly over his "sweet sinner."

No matter how much Spenser contemplated Heavenly Beauty, he was "thrall to his passion" for sensuous beauty. Again and again he refers to the fascination of beauty over the senses:

"Nought under heaven so strongly doth allure The sence of man, and all his minde possesse, As beauties lovely baite,..$\ldots \ldots \ldots \ldots \ldots \ldots$. 1 $\begin{array}{llllll}\mathrm{x} & \mathrm{x} & \mathrm{x} & \mathrm{x} & \mathrm{x} & \mathrm{x}\end{array}$

"To captive men and make themall the world reject."

Referring to the "antique age" before corruption came into the world, Spenser showed the descent from the Platonic ideal to the decadence of the Renaissance:

"Then beautie, which was made to $r$ epresent The great Creatours owne resemblance bright, Unto abuse of lawlesse lust was lent, And made the baite of bestiall delight:

Then faire grew foule, and foule grew faire in sight, And that which wont to vanquish God and man Was made the vassall of the victors might." 3

Also

"... oft it palles (ay me, the more to rew!) That goodly Beautie, albe heavenly borne, Is foule abusd, and that celestiall hew, Which doth the world with her delight adorne,

1. F.Q., V, vii, 1 .

2.

3. F.?., IV, vii, 32 . 
Made but the bait of sinne, and sinners scorne; Whilest every one doth sedke and sell to have it, But every one doth seeke but to deprave it.ill

Beauty inspires love and its opposite - lust.

"Wonder it is to see in diverse mindes How diversly Love doth his pageaunts play,

And hewes his powre in variable kindes:

The baser wit, whose ydle thoughts alway

Are wont to cleave un to the lowly clay,

It stirreth up to sensuall desire,

And in lewd slouth to wast his carelesse day:

But in brave sprite it kindles goodly fire,

That to all high $\mathrm{d}$ esert and honour doth a spire." 2

The effect depends upon the beholder. The matchless

beauty of the true Florimell incites only lust in the

base-born son of the witch in whose house Florimell seeks

shelter. Amoret's charms serve merely to whet the

appetite of the wicked Busirane. Serena's innocent

beauty made the only appeal possible to primitive man -

the sense appeal; but even the savages were stayed from destroy-

ing her for their own enjoyment, holding her sacred as a sacrifice for the gods.

The Faery Queene is Puritan in conception but, to a great extent, Renaissant in execution. In his lett 2 to Sir Walter Raleigh, Spenser stated a definite moral purpose in his great poem - that of giving moral instruction, by example rather than by precept, in a delightful manner. His aim was "to fashion a gentleman inv ertuous

1. "An Hymne in Honour of Beautie," 11. 148-154. 2. F.2., III, v, I. 
discipline," - a worthy Puritan ambition. His plan was to have virtues assailed by vices with the final, though not necessarily easy, triumph of the good. All this the poet achieved; yet he was too thoroughly a man of his time to leave out that characteristic which definitely marked the Renaissance - a delicious enjoyment in sensuous beauty. Spenser's boundless enthusiasm carried him at times beyond the pale of decency; yet he always recoiled. The Faerie Queene is an unusual combination of moral seriousness with sensuous delight, what Jusserand calls a "mixture of bacchanals and sermons."I

Spenser could go from thedepths of voluptuousness to the heights of the sublime. There is in his poetry evidence of continual conflict between the strong instincts of purity and right and the passionate appreciation of every charm, ${ }^{2}$ a feature which one may justly interpret as autobiographical. The struggling nature reaching out aft er the beauty of heaven could not tear itself from the beauty of earth. In this, then, I believe, consists the paradox: two equally strong forces striving for mastery - the high-mindedness and moral seriousness of the Puritan Platonist versus the unrestraint and sensuousness of the Renaissance devot ee.

1. Jusserand, J A A Literary History of the English People, p. 499 .

2. Church, R.W., op. cit., p. 16. 
HARMONI ZATION OF CONTRASTING FCRCES 


\section{HARMONIZATION OF CONTRASTING FORCES}

Two directly opposing forces of Spenser's nature have been presented. How can they be accounted for? What is the result? These questions can be briefly answered. My conclusion is that these forces were not irreconcilable; Spenser harmonized them so skillfully that one is not always aware of the struggle within him. It is not difficult to account for this pronounced two-sidedness if one but remmers that Spenser lived in an age of transition and of intense activity. Reaping on one side the fulness of the Renaissance with its many-sided interests, Spenser also felt on the other the reaction of Puritanism in all its intensity. Elizabethan society, reflecting the personality of the queen, was on one hand gay, pleasure-loving, unrestrained, and at times coarse. ${ }^{1}$ Puritanism, on the other hand, was a powerful force. "Camden assigns the rise of Puritanism in England to the year 1568, a date which may be accepted if we take it as simply marking the time when the leaders of the movement came into open conflict with the Government, and when Puritanism began to make itself reckoned with. Its realprigin, however, was much earlier. Indeed, that desire for a more scriptural worship, and that spirit of resistance to sacerdotali sm and church ceremies which 1. Traill, H.D., Social England, p. 383. 
constituted the very essence of Puritans, may be traced back even for centuries before the Reformation."I Of a receptive, passive nature, Spenser could not fail to be greatly influenced by the dominating forces of his time. "His imagination received an impulse from every one of the great sources of thought which in the sixteenth century were agitating the mind of Europe. Catholic Theology, Medieval Romance, the Philosophy of the Renaissance, the Morality of the Reformation, all contributed elements to the formation of his poetical conceptions." 2 The rich life of the Renaissance fired Spenser's imagination; the purging moral reaction of Puritanism stirred his soul. At each shrine in turn he worshipped, but he did not give himself up wholly to either. That fact, I believe, explains why Spenser was able to fuse and blend "the severe Christian ecstasy and the warm Greek joy in life, a holy sensuousness." 3

An exolanation of the fusing of opposing forces in Spenser's character is found in his philosophy of the Golden Mean. So much was the poet absorbed in this philosophy of Aristotle that he devoted a whole book to the subject of temperance, which ideal he 1. Traill, H. D., Op. cit., pp. 424-25.

3. Courthope, W. J., Hi story of English Poetry, p. 234. 3. Cory, H. E., Op. cit., p. 251 . 
doubtless succeded in attaining in his own life. Temperance, Spenser held, was necessary to peace and satisfaction.

"When raging passion with fierce tyranny Robs reason of her dew $r$ egalitie And makes it servaunt to her basest part, The strong it weakens with infirmitie, And with bold furie armes the weakest hart: The strong through pleasure soon est falles, the weake through smart.

'But Temperaunce,' said he (Guyon), 'the golden squire

Betwixt them both can measure with the meane, Nether to meet in pleasures whott desyre, Nor fyre in hartless griefe and dolefull tene!" I

Temperance is ever armed with reason, which as a companion of Guyon is personified as

"...... that blacke palmer, hi s most trusty guide, Who suffred not his wandring feete to slide; But when strong passion, or weake fleshlinesse, Would from the right way seeke to draw him wide, He would, through temperaunce and st ed fastnesse, Teach him the weak to strengthen, and the strong suppresse." 2

Medina, or Golden Mean, far excelled her two sisters Elissa and Perissa, the two Extremities, who tried to banish her but over whom she triumphed. May not the allegory of the sisters refer to Spenser personally? One temperament served to counterbalance the other; and Spenser, accordingly, was spar ed from going to either extreme.

John Erskine, pointing out Spenser's keen

1. F.?., II, 57 and 58 .

2. F.2., II, iv, 2 . 
sensibility to physical charm and also his emphasis on beauty of the soul, aptly says: "The two worlds, spiritual and physical, derived in a literary sense from Plato on the one hand and from Italy on the other, are to him not antithetical but complementary."I Spenser's peculiar temperament - his receptive power, his gemine versatility, his ability of adaptation accounts for the paradoxical elements in his nature. The two contradictory forces, running side by side, in reality do not conflict. The classical world appealed to the artist Spenser; he partook of all the sensuous joy of the Renaissance. Yet the restraining doctrine of Puritanism influenced the moralist spenser. The conflict resulted, then, into an opposition between the artist and the moralist. Spenser, however, was too much of an artist to sacrifice art to the limitations of a narrow moral code. He was a poet before he was a preacher. His aim - though to teach - was to teach delightfully. His "moral idealism and his exquisite sense of beauty met and became inseparably involved." 2 Spenser was a product of his age, receiving unto

1. Erskine, John, The Elizabethan Lyric, p. 156.

2. Dowden, mdward, Transcripts and Studies, "Heroines of Spenser, " p. 309. 
himself all the variant and opposing streams of influence, uniting them, and sending them forth in one great harmonious whole. The two forces Renaissance delight in life and Puritan idealism become reconciled and harmonized in "the poet's poet" - Edmund Spenser. 
BIBLI OCRAPHY 
Arnold, Matthew, St. $\frac{\text { Paul }}{\text { New }} \frac{\text { and }}{\text { York, Thetestantism, }}$, Wacmillan Company, 1902. The Americana (Biography of Edmund Spenser by Professor Fl etcher ), New York, Am ericana Corp., 1927.

Boas and Hahn, Social Backgrounds of Engli sh Literature, Boston, The Atlantic Wonthly Press, 1923.

The Britannica ("Renai ssance"), New York, Scribner, 1878-88.

Campbell, Douglas, The Puritan in Holland, England, and America, VoI. I, New York, Harper, 1893.

Cambridge History of English Literature, Vol. III, Ch. xi, ("The Poetry of Spenser"-W. J. Courthope) New York, Putnam, 1907.

Carpenter, F. I., A Refer ence Guide to Edmund Sp enser, chicago, The Univ ar aity of Chicago Press, 1923.

Child, F. J., Fdmund Spenser - Poetical Works, "Memolr of Spenser," VOI. I, 1871 .

Church, R. W., Spenser, New York, Harper and Brothers (E.M.L. Series), 1902.

Clark, Donald L., Rhetoric and Poetry in the Renaissance, New York, Columbia University Press, 1922.

Clavière, R. de Maude, translated by Herbert Ely, The Women of the Renaissance, New York, G.P. Putnam's Sons, 1901.

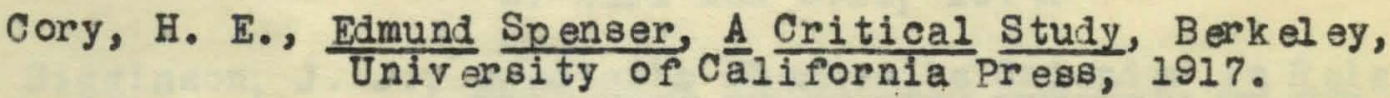

Courthope, W. J., A History of English Poetry, Vol. II, New York, The Kacmilian Company, 1895-1905.

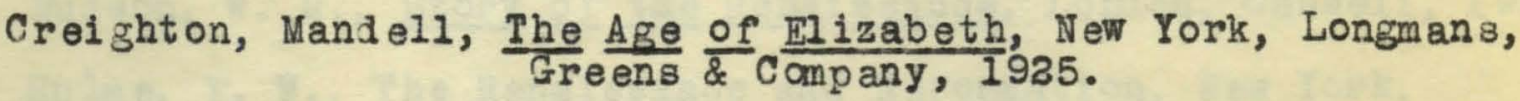

Dodge, R. E. N., ed., Spenser's $\frac{\text { Complete Poens, Boston, }}{\text { Houghton }}$ Mifflin and Company, 1908 .

Donne, J., $\frac{\text { Poetical Forks, Boston, Little, Brown, and Company, }}{1855}$,

Dowden, Eaward, Transoripts and Studies, Lond on, Kegan Paul, Trench, Tribner and Company, Ltd., 1896.

Einstein, Lewis, The Italian Renaissance in England, New York, Columbia University Pres8, 1905. 
Erskine, J., The Elizabethan Lyric, New York, Columbia Universi ty Press, $19 \mathrm{cs}$.

Fl etcher, J. B., The Religion of Beauty in Woman, Nell York, The Macmillan company, 1911.

Fletcher, J. B., "A Study in Renaissance Mysticism - Spenser's Fowre Hymnes, " PMLA, XXVI, 1911.

Fowler, E. B., Spenser and the Courts of Love, Doctorate Thesis, University of Chicago, 1921.

Gardiner, S. R., The First Two Stuarts and the Puritan Revolution, Boston, Estes, 1876 .

Gardiner, S. R., History of England, New York, Longmans, 1920.

Green, John R., History of the English People, Vol. III, N ew York, Harper and Brothers, 1879-1880.

Hannay, David, The Later Renaissance, New York, C. Scribner's Sons, 1898 .

Harrison, J. S., Platoniam in Engli sh Poetry of the Sixteenth and Sev anteenth Centuries, New York, Columbia Univer sity Press, 1903.

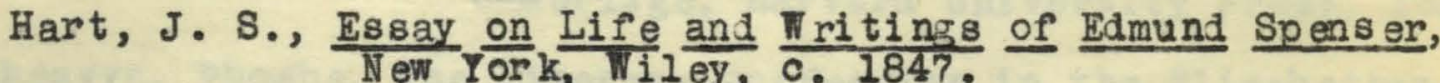

Haslewood, J., Ancient Critical Essays upon English Poets and Poesy, London, Robert Triphook, 1815 .

Hazlitt, william, Lectures on the $\frac{\text { Age }}{\text { G. Bell }} \frac{\text { of }}{\text { andizabeth, Lond on, }}$

Higgingon, J. J., Soenser's Shepherd's Calender in Relation to Contemporary Affairs, New York, Columbia University Press, 1912.

Hudson, W. H., Story of the Renaissance, London, Casse11, 1912.

Hu Ime, E. M., The Renaissance and Reformation, New York, The Century Company, 1917.

Hunt, J. H. L., Storieg from the Italian Poets, New York, New Yor $\mathrm{k}$, Wiley, 1846 .

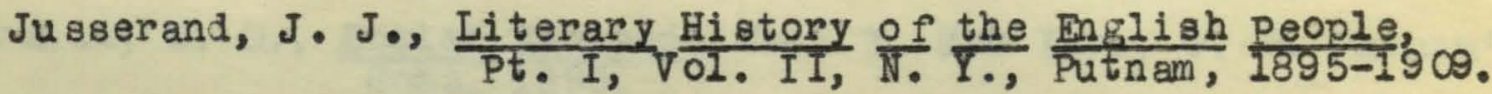

Lee, Sidney, Great Englishmen of the Sixteenth Century, New york, C. Soribner' 8 Son 8, 1904 . 
Legouis, Fmile - translated by Hel en D. Irwine - A History of English Literature, New York, The Macmilian Company, 1926 .

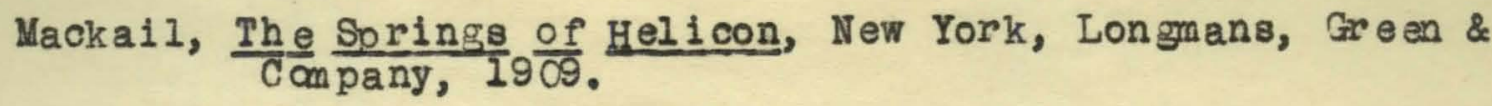

The Nation, November 21, 1912, p. 486.

Neal, Daniel, History of the Puritans, London, Tegg, 1837.

Padelford, F. M., "Spenser and the Puritan Propaganda," Modern Philology, XI, 1913.

"Spenser and the Spirit of Puritanism," Modern Philology, XIV,1916.

"Spenser and the Theology of Calvin," Modern Philology, XII, 1914.

Robertson, J.M., Elizabethan Literature, Home University Library, New York, H. Holt and Company, 1914.

Saint sbury, G. E., The perlier Renaissance, New York, Scribner, 1901.

Schofield, . H., Chivalry in English Literature: Chaveer, Malory, Spenser, and Shak espeare, cambridge, Harvard University Press, 1912.

Sheavyn, Phoebe, The Literary profession in the Elizabethan Age, Manchester University Press, 1909.

Spingarn, J. E., A History of Literary Criticism in the Renaissance, New York, Columbia Universi ty Press, 1925.

Stephen, Leslie, and Lee, Sidney, eds., Dictionary of National Biography, Vol. LIII, New York, The Macmillan Company, 1885-1901.

Taylor, H. O., Thought and Expression in the Sixteenth Century, NeW York, The Macmillan Company, 1920.

Temple, O. Po, Covenanter, the Cavalier and the Puritan,

Tolman, A. H., The Relation of Spenser and Harvey to Puritani m, Modern Philo10gy, XV, 1918.

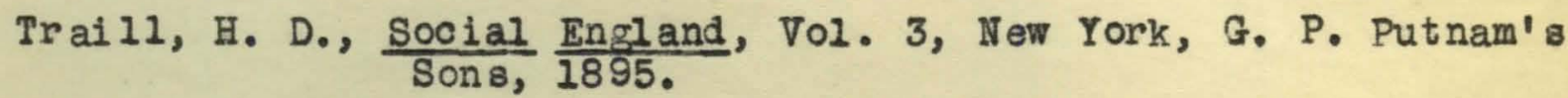

Wilson, John, Blackwood's Magazine, XXXIV, November, 1833, p.852.

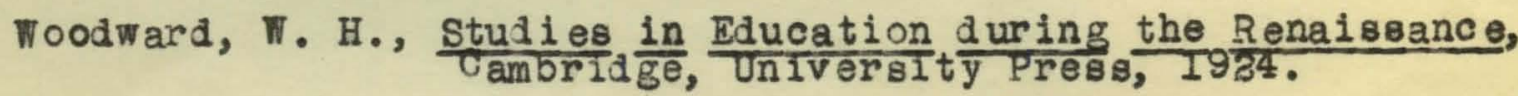

